\title{
Growth and yield of Coffea arabica L. in Northwest Fluminense: $2^{\text {nd }}$ harvest $^{1}$
}

\author{
Weverton Pereira Rodrigues ${ }^{2}$, Henrique Duarte Vieira ${ }^{3}$, Dimmy Herlen Silveira Gomes Barbosa ${ }^{4}$, Cássio Vittorazzi
}

\begin{abstract}
In recent years, several new coffee cultivars recommended for different regions have been released. However, the performance of these varieties in many traditionally producing regions is unknown. Difference of climate and soil may jeopardize the productivity of the new cultivars and cause losses to farmers. The objective of this study is to evaluate the vegetative growth and productive genotypes of $C$. arabica in the conditions of the Northwestern Rio de Janeiro State, Brazil. The experiment was settled in 2007, in Panorama 1 Farm, located in the municipality of Varre Sai, RJ. Twenty-five genotypes of $C$. arabica were planted in a spacing of $2.5 \times 0.8 \mathrm{~m}$, using a completely randomized design with five replications and eight plants per plot. There were eight measurements of vegetative growth represented by plant height, stem diameter and number of plagiotropic branches. Assessments of productivity were also performed in years 2009 and 2010. There was a positive phenotypic correlation among vegetative characteristics and between vegetative characteristics and yield in the first harvest, while in the second harvest only the number of plagiotropic branches was positively correlated with yield. Up to date, the genotypes Catucaí amarelo 2 SL, Catiguá MG 02, Acauã, Palma II, Sabiá 398, IPR 103/ Iapar, IPR 100/Iapar, H 419-10-6-2-12-1, Catucaí amarelo 24 / 137, Iapar 59, Catucaí amarelo 20/15, H 419-10-6-2-5-10-1 and H 419-10-6-2-5-1 had the highest average yield after two harvests.
\end{abstract}

Key words: coffee, production, genotype.

\section{RESUMO}

\section{Crescimento e produtividade de Coffea arabica L. na região Noroeste Fluminense:}

\section{$2^{\circ}$ Colheita}

Nos últimos anos foram lançadas várias cultivares de café recomendadas para diversas regiões. Porém, o conhecimento da resposta dessas variedades em outras regiões tradicionalmente produtoras é desconhecido, o que pode uma vez plantado nestas regiões, comprometer a produtividade dos genótipos devido às diversidades edafoclimáticas, causando prejuízo aos produtores. O presente trabalho tem como objetivo avaliar o crescimento vegetativo e produtivo de genótipos de $C$. arabica nas condições do Noroeste Fluminense do Estado de Rio de Janeiro. O experimento foi instalado em 2007, na Fazenda Panorama 1 localizada no município de Varre Sai - RJ. Foram avaliados 25 genótipos de café arábica, no espaçamento de 2,5 x 0,8m sendo o delineamento utilizado no experimento o inteiramente casualizado com cinco repetições, sendo oito plantas por parcela, totalizando 1000 plantas. Foram realizadas oito avaliações para desenvolvimento vegetativo utilizando a altura da planta, diâmetro do caule e o número

\footnotetext{
Received for publication on October $05^{\text {th }}, 2011$ and approved on August $29^{\text {th }}, 2012$.

'This work is part of the Master's degree dissertation of the first author, funded by Fundação de Amparo à Pesquisa do Estado de Rio de Janeiro.

${ }^{2}$ Agronomist. Master degree Student at Universidade Estadual do Norte Fluminense, Avenida Alberto Lamego, 2000, 28013-602, Campos dos Goytacazes, Rio de Janeiro, Brasil. wevertonuenf@hotmail.com (corresponding author).

${ }^{3}$ Agronomist, Doctor. Laboratório de Fitotecnia, Centro de Ciências e Tecnologia Agropecuária, Universidade Estadual do Norte Fluminense, Avenida Alberto Lamego, 2000, 28013-602, Campos dos Goytacazes, Rio de Janeiro, Brasil. henrique@uenf.br

${ }^{4}$ Agronomist, Doctor. Embrapa Mandioca e Fruticultura, Núcleo de Recursos Genéticos e Desenvolvimento de Variedades, s/n, 44380-000, Cruz das Almas, Bahia, Brasil. dimmybarbosa@hotmail.com

${ }^{5}$ Agronomist. Master degree Student at Universidade Estadual do Norte Fluminense, Avenida Alberto Lamego, 2000, 28013-602, Campos dos Goytacazes, Rio de Janeiro, Brasil. vittorazziuenf@hotmail.com
} 
de ramos plagiotrópicos. Também foram realizadas avaliações da produtividade do ano de 2009 e 2010. Houve correlação fenotípica positiva entre as características vegetativas e entre as características vegetativas e a produtividade na primeira colheita, sendo que, na segunda colheita apenas o número de ramos plagiotrópicos correlacionou positivamente com a produtividade. Até o momento, os genótipos Catucaí Amarelo 2 SL, Catiguá MG 02, Acauã, Palma II, Sabiá 398, IPR 103/Iapar, IPR 100/Iapar, H 419-10-6-2-12-1, Catucaí Amarelo 24/137, Iapar 59, Catucaí Amarelo 20/15, H 419-10-62-5-10-1 e H 419-10-6-2-5-1 apresentaram a maior produtividade média na avaliações das duas colheitas.

Palavras-chave: café, produção, genótipo.

\section{INTRODUCTION}

The state of Rio de Janeiro, is currently facing difficulties in promoting the expansion of coffee cropping area. In addition to old problems such as orange rust (Hemileia vastratrix Berk et Br.) and root-knot nematode (Meloidogyne exigua Goeldi, 1887), the maintenance of old and depleted fields and lack of improved cultivars adapted to the ecological conditions of Rio de Janeiro has hindered the recovery of coffee plantations in the state.

Rio de Janeiro state shows to be promising for the expasion of the crop, since coffee consumption in the state is approximately 1.3 million bags a year. It is noteworthy that Rio receives annually about one million foreign tourists, which increases the state's responsibility to provide high quality products (Centro do Comércio de Café do Rio de Janeiro, 2010).

The Public Policies of incentive, as well as the transmission of technology from research companies to the extension organs coupled with the willingness of farmers to change the current scenario is essential for the expansion of cropped area and increase the productivity of coffee in the state.

In Brazil, from 1999 to 2011, 105 improved cultivars of coffee were made available to farmers (Brasil, 2011). Of this total, 49 have vertical or horizontal resistance to $H$. vastatrix (Castillo, 1989; Alvarado, 2005) and some are resistant to M. exigua, which is found in more than $50 \%$ of the crops of the state of Rio de Janeiro, where they cause yield losses of up to $45 \%$ (Barbosa et al., 2004).

With the aim of increasing yield, coffee breeding programs have attempted to release cultivars adapted to each region and management and resistant to major pests and diseases. However, due to the great climatic diversity among production regions, it becomes necessary to study the local adaptation of these new cultivars to minimize future risks.

The knowledge of the vegetative and productive characteristics is important to compare and evaluate their performance in a certain region. After a long period evaluating yield, resistance to pests and diseases, pruning system and management, it becomes possible to recommend one or more cultivars (Matiello et al., 2009)
Because coffee is a perennial crop, it requires a trial period of several years of continuous evaluation of production, in order to estimate the total potential production of cultivars. Thus, the time spent, as well as the demands of large experimental areas make the coffee breeding programs expensive. In this regard, coffee breeding programs aiming at selection of superior genotypes based on the production of the first years would be advantageous (Bonomo et al., 2004). The main selection criterion in coffee crops is productivity (Carvalho et al., 1961; Srinivasan, 1982). Other agronomic traits related to yield potential have been studied in order to increase the efficiency of indirect selection (Severino $e t$ al., 2002). Freitas et al. (2007) reported the possibility of success of early selection (at 12 months) for indirect yield, using growth traits related to production.

This study aims to evaluate the vegetative and production characteristics of 25 genotypes of arabica coffee in the Northwest region of Rio de Janeiro state.

\section{MATERIALS AND METHODS}

The experiment was settled in 2007 in Panorama 1 Farm, in the municipality of Varre Sai-RJ, in an Oxisol, located at $20^{\circ} 55^{\prime} 52^{\prime \prime} \mathrm{S}$ and $-41^{\circ} 52^{\prime} 07^{\prime \prime} \mathrm{W}$, with average altitude of 680 meters. The climate is typical tropical highland, showing average annual temperature of $19.0^{\circ} \mathrm{C}$ and average annual rainfall of $1601 \mathrm{~mm}$ (Martorano et al., 2003).

Seeds of 25 genotypes of $C$. arabica used in the experiment (Table 3) were provided by Empresa de Pesquisa Agropecuaria de Minas Gerais (EPAMIG).

The 25 genotypes were planted at a spacing of $2.5 \times$ $0.8 \mathrm{~m}$ in a completely randomized design with five replications and eight plants per plot. Evaluations were made of vegetative growth, using a graduated ruler for measuring plant height; a digital caliper Starret ${ }^{\circledR}$ for measurement of stem diameter at ground level; and number of plagiotropic branches were counted. The harvests of 2009 and 2010, which were performed by boltering when plants had $80 \%$ of ripe fruit (cherry), were evaluated. The harvested bulk was transformed into bags of processed coffee/ha (bag ha ${ }^{-1}$ ), using a proportion of 480 liters of coffee cherries to yield a $60 \mathrm{~kg}$ bag. The variables were 
subjected to analysis of variance and means grouped by the Scott Knott test at 5\% probability. Also, Person coefficients of correlation between variables were estimated. All analyses were performed using the Genes Statistical Analysis Software (Cruz, 2006).

\section{RESULTS AND DISCUSSION}

The analysis of variance showed that there were significant differences between genotypes regarding plant height, stem diameter and number of plagiotropic branches (Table 1).

Table 2 shows that genotypes differ regarding yield for both years, 2009 and 2010, and of the average yield for the two years.

For plant height, the genotype Bourbon Amarelo LCJ 10 was in the group of the highest means (Table 3 ). This was probably due to individual genetic factor of these genotype, characterizing the genotype $\mathrm{X}$ environment interaction, which may have been enhanced by the narrow spacing, since the competition for light between plants, as spacing reduces, results in greater development in height. Rena et al. (1998), studying populations of $C$. arabica variety Catuaí, in Patrocínio - MG, found that 30 to 54 months after planting, plant height increased linearly and stem diameter decreased with the reduction of spacing. The genotypes Catucaí Amarelo 2 SL, Catiguá MG 2, Catucaí Amarelo 24/137 and Sacramento MG 1 were in the intermediate group for height (Table 3 ).
Regarding the stem diameter, the genotypes Catucaí Amarelo 2 SL, IPR 100, Catucaí Amarelo 20/15, Sacramento MG 1 and Bourbon Amarelo LCJ10 were in group of higher averages (Table 3). Genotypes were in the group of middle and upper middle group averages for plant height also presented the group with the highest means for stem diameter, explaining the growth synchrony between this two variables to support the plant. For number of plagiotropic branches, the genotypes Catucaí Amarelo 2 SL, Catiguá MG 2, Araponga MG 1, IPR 103, IPR 100, H 419-3-3-3-716-4-1, Catucaí Amarelo 24/137, Catucaí Amarelo 20/15, Catiguá MG 1, H 419-10-6-2-5-10-1, Sacramento MG 1, Pau Brasil MG 1 and H 419-10-6-2-5-1 were in group of higher averages (Table 3 ).

With regard to yield, in the first harvest in 2009, the genotypes Catucaí Amarelo2 SL, Catiguá MG 02, Sabiá 398, IPR 103, IPR 100/, Catucaí Amarelo 24/137, Catucaí Amarelo 20/15, IPR 104/ and H 419-10-6-2-5-1 were in the group of the highest means (Table 4). Interestingly, the genotype of the group Catucaí, which presented the highest average yield in 2009, also had the greatest mean plant height, showing that this variable was important for this group in the first harvest. In the second harvest, in 2010, the genotypes Catiguá MG 02, Acauã, Palma II, IPR 103/, IPR 100/, H 419-10-6-2-12-1, Iapar 59 and H 419-10-62-5-10-1 were in the group of the highest means (Table 4).

On the average of the two crops, the genotypes Catucaí Amarelo 2 SL, Catiguá MG 02, Acauã, Palma II, Sabiá 398, IPR 103/, IPR 100/, H 419-10-6-2-12-1, Catucaí

Table 1. Summary of analysis of variance and coefficients of variation of plant height, stem diameter and number of plagiotropic branches of 25 coffee genotypes settled in the Northwestern Rio de Janeiro state

\begin{tabular}{lcccc}
\hline \multicolumn{5}{c}{ MS } \\
\hline SV & DF & $\begin{array}{c}\text { Plant height } \\
(\mathbf{c m})\end{array}$ & $\begin{array}{c}\text { Stem diameter } \\
(\mathbf{m m})\end{array}$ & $\begin{array}{c}\text { Number of } \\
\text { plagiotropic branches }\end{array}$ \\
\hline Genotype & 24 & $703.54^{* *}$ & $24.94 * *$ & $76.15^{* *}$ \\
Residue & 100 & 129.57 & 5.28 & 17.92 \\
\hline Total & 124 & & & 6.64 \\
\hline CV\% & - & 7.57 & 5.32 & \\
\hline
\end{tabular}

** Significant at $1 \%$ probability.

Table 2. Summary of the analysis of variance and coefficients of variation of productivity from the years 2009 and 2010 and average of two yields from 25 coffee genotypes settled in the Northwestern Rio de Janeiro state

\begin{tabular}{lcccc}
\hline \multicolumn{5}{c}{ MS } \\
\hline SV & DF & $\begin{array}{c}\text { Productivity 2009 } \\
\left(\text { bag ha }^{-1}\right)\end{array}$ & $\begin{array}{c}\text { Productivity 2010 } \\
\left.\text { (bag ha }^{-1}\right)\end{array}$ & $\begin{array}{c}\text { Average productivity } \\
\text { (bag ha }^{-1} \text { ) }\end{array}$ \\
Genotype & 24 & $423.18^{* *}$ & $354.24^{* *}$ & $229.88^{* *}$ \\
Residue & 100 & 177.52 & 125.47 & 9.00 \\
\hline Total & 124 & & & 21.32 \\
\hline CV\% & - & 27.53 & 32.03 & \\
\hline
\end{tabular}

** Significant at $1 \%$ probability. 
Amarelo 24/137, Iapar 59, Catucaí Amarelo 20/15, H 419 10-6-2-5-10-1 and $\mathrm{H}$ 419-10-6-2-5-1 were in the group of higher averages (Table 4). However, the genotypes Catiguá MG 02, IPR 103 and IPR 100/ were in the group of the highest means in 2009 and 2010 (Table 4). These genotypes showed no effect of yield biennially or had reduced effect, showing good adaptation to the region. The same happened with the genotypes Acauã, Palma II, H 419-10-6-2-12-1, Iapar 59 and H 419-10-6-2-5-10-1, which showed no significant difference in production between the years although they do not belong in the group of the highest means for the two harvests.

It is worth noting that the genotypes Catiguá MG 02, IPR 103/ and IPR 100/are not in the group of the highest means for plant height, which is beneficial considering the harvest of the following years. Breeding programs have sought to select shorter plants, once they facilitate the harvesting and cultivation and, in high density planting systems, provide higher yields per unit area compared with tall plants (Sakiyama et al., 1999).

The two year yield mean is important since it is coupled the homogeneity of productivity. So it is worth noting the performance of the genotypes Catiguá MG 02, IPR 103/, IPR 100/, Acauã, Palma II, H 419-10-6-2-12-1, Iapar 59 and H
419-10-6-2-5-10-1 (Table 4), once they have maintained good productivity. According to Matiello et al. (2009), a good crop productivity is the basis for reducing the cost of coffee production and, therefore, it is very important to generate adequate revenue to farmers. Catuaí vermelho, widely planted in the region, was in the group of lower means yields of 2009 and 2010, demonstrating that it is possible to replace it with more modern and productive genotypes, and resistant to Hemileia vastatrix.

The genotypes that stood out so far are resistant to $H$. vastatrix. Some genotypes are already cropped, such as Catiguá MG 02, IPR 103/, IPR 100/, Acauã and Iapar 59, and others that are still not cropped, such as H 419-10-62-12-1 and $\mathrm{H}$ 419-10-6-2-5-10-1. This shows that, so far, new genotypes may be an option for the Northwest Fluminense. As these genotypes are from a crossbreeding involving Timor Hybrids, few more years of evaluation becomes necessary, in order to show the ability to produce in a more stable and less expensive system than the varieties used to date, ensuring greater return to farmers.

According to Matiello et al. (2009), coffee varieties originated from the crossbreeding involving the Timor Hybrid show resistance to coffee leaf rust and good productivity in the first harvests. However, after the third

Table 3. Means of plant height $(\mathrm{cm})$, stem diameter $(\mathrm{mm})$ and number of plagiotropic branches from 25 coffee genotypes settled in the Northwestern Rio de Janeiro state.

\begin{tabular}{lccc}
\hline Genotypes & Plant height & Stem diameter & Number of plagiotropic branches \\
\hline 1-Catucaí Vermelho785/15 & $146.00 \mathrm{c}$ & $42.38 \mathrm{~b}$ & $53.66 \mathrm{~b}$ \\
2-Catucaí Amarelo 2 SL & $168.86 \mathrm{~b}$ & $46.20 \mathrm{a}$ & $64.22 \mathrm{a}$ \\
3-IPR/ Iapar & $132.68 \mathrm{c}$ & $40.46 \mathrm{~b}$ & $60.32 \mathrm{~b}$ \\
4-Catiguá MG 2 & $158.22 \mathrm{~b}$ & $45.86 \mathrm{a}$ & $64.86 \mathrm{a}$ \\
5-IPR 99/ Iapar & $139.22 \mathrm{c}$ & $43.00 \mathrm{~b}$ & $59.92 \mathrm{~b}$ \\
6-Acauã & $144.30 \mathrm{c}$ & $42.10 \mathrm{~b}$ & $63.36 \mathrm{~b}$ \\
7-Araponga MG 1 & $154.62 \mathrm{c}$ & $43.88 \mathrm{~b}$ & $65.18 \mathrm{a}$ \\
8-Palma II & $147.06 \mathrm{c}$ & $41.80 \mathrm{~b}$ & $59.64 \mathrm{~b}$ \\
9-Sabiá 398 & $139.54 \mathrm{c}$ & $41.96 \mathrm{~b}$ & $60.10 \mathrm{~b}$ \\
10-IPR 103/Iapar & $153.10 \mathrm{c}$ & $43.64 \mathrm{~b}$ & $68.96 \mathrm{a}$ \\
11-IPR 100/Iapar & $155.66 \mathrm{c}$ & $45.76 \mathrm{a}$ & $70.22 \mathrm{a}$ \\
12-H 419-3-3-3-716-4-1 & $150.38 \mathrm{c}$ & $43.64 \mathrm{~b}$ & $64.80 \mathrm{a}$ \\
13-H 419-10-6-2-12-1 & $134.94 \mathrm{c}$ & $40.86 \mathrm{~b}$ & $63.40 \mathrm{~b}$ \\
14-Catucaí Amarelo 24/137 & $163.22 \mathrm{~b}$ & $42.88 \mathrm{~b}$ & $68.14 \mathrm{a}$ \\
15-Iapar 59 & $144.98 \mathrm{c}$ & $42.48 \mathrm{~b}$ & $61.30 \mathrm{~b}$ \\
16-Oeiras & $144.28 \mathrm{c}$ & $40.86 \mathrm{~b}$ & $60.70 \mathrm{~b}$ \\
17-Catuaí Vermelho144 & $147.94 \mathrm{c}$ & $41.64 \mathrm{~b}$ & $62.52 \mathrm{~b}$ \\
18-Catucaí Amarelo 20/15 & $153.34 \mathrm{c}$ & $45.60 \mathrm{a}$ & $65.84 \mathrm{a}$ \\
19-Catiguá MG 1 & $145.74 \mathrm{c}$ & $41.16 \mathrm{~b}$ & $64.32 \mathrm{a}$ \\
20-H 419-10-6-2-5-10-1 & $142.36 \mathrm{c}$ & $42.82 \mathrm{~b}$ & $36.56 \mathrm{a}$ \\
21-IPR104/Iapar & $139.88 \mathrm{c}$ & $41.64 \mathrm{~b}$ & $61.84 \mathrm{~b}$ \\
22-Sacramento MG 1 & $172.14 \mathrm{~b}$ & $47.38 \mathrm{a}$ & $70.18 \mathrm{a}$ \\
23-Bourbon Amarelo LCJ10 & $183.06 \mathrm{a}$ & $48.24 \mathrm{a}$ & $60.42 \mathrm{~b}$ \\
24-Pau Brasil MG 1 & $153.16 \mathrm{c}$ & $43.94 \mathrm{~b}$ & $68.64 \mathrm{a}$ \\
25-H 419-10-6-2-5-1 & $142.08 \mathrm{c}$ & $39.54 \mathrm{~b}$ & $64.78 \mathrm{a}$ \\
\hline Mers & $5610 w \mathrm{Kn}$ &
\end{tabular}

Means followed by same letter do not differ by Scott Knott test at 5\% probability. 
or fourth harvests the plants become to degenerate, due to low vigor. A good example is the variety Iapar 59 in the mountainous region of Minas Gerais, which has shown good response to the third harvest.

Positive correlations were observed between plant height and stem diameter, plant height and number of plagiotropic branches and stem diameter and number of plagiotropic branches (Table 5). Evaluating five phenological characters of 19 varieties of arabica coffee in the municipality of Brejão - PE, Freitas (2004) reports correlations between stem diameter and plant height, number of branches, length of primary branches and number of internodes.

Positive correlations were also observed between vegetative characteristics and productivity in 2009 (Table 5). This shows that plants that have good initial development can provide good yields in the first harvest.

Silvarolla et al. (1997) evaluated 57 progenies of the Timor Hybrid and found a correlation between productivity and vegetative characters. On the average of four harvests, the authors obtained a high phenotypic correlation of productivity gained by plant height and crown diameter.

Carvalho et al. (2010) evaluated the initial performance of 25 varieties of arabica coffee in the spacing of $3.5 \times 0.7$ $\mathrm{m}$ in three regions of Minas Gerais and report that the characteristics that showed higher phenotypic correlation with yield were the number of plagioropic branches, plant height and length of plagiotropic branches .

Martinez et al. (2007) studied four cultivars of arabica coffee in the city of Ervália - MG, and report that in the spacing of $2.5 \times 0.75 \mathrm{~m}$, the correlation between production and the number of plagiotropic branches was not significant at 48 months after planting. The vegetative characteristics of coffee satisfactorily explained the variation in productivity. According to the authors, the taller plants tended to produce more at 20 months, regardless of space used and only at 33 months in a spacing of 2,5 $\mathrm{m} \times 0,75$, and, in a $1 \times 0,75 \mathrm{~m}$ spacing, the development of plant height competed with the grain production. However, for the Northwestern Fluminense, 40 months after planting (by second harvest), the only variable that showed a positive correlation was the number of plagiotropic branches (Table 6). This may have occurred because of the biennially of the coffee crop, which was evident in some genotypes. Miranda et al. (2005) evaluated the first three harvests of F5 progeny from crosses between Yellow Catuaí and Timor Hybrid, and found correlations between yield and vegetative traits, and the

Table 4. Means of productivity of hulled coffee (bags $60 \mathrm{Kg}_{\text {hectare }}{ }^{-1}$ ) from 2009 and 2010 and average of two yields of 25 coffee genotypes in the Northwestern Rio de Janeiro state

\begin{tabular}{lccc}
\hline Genotype & $\mathbf{2 0 0 9}$ & $\mathbf{2 0 1 0}$ & Average productivity \\
\hline 1-Catucaí Vermelho 785/15 & $27.50 \mathrm{~b}$ & $34.28 \mathrm{~b}$ & $30.89 \mathrm{~b}$ \\
2-Catucaí Amarelo 2 SL & $57.63 \mathrm{a}$ & $32.22 \mathrm{~b}$ & $44.93 \mathrm{a}$ \\
3-IPR/ Iapar & $41.66 \mathrm{~b}$ & $29.64 \mathrm{~b}$ & $35.65 \mathrm{~b}$ \\
4-Catiguá MG 2 & $61.78 . \mathrm{a}$ & $53.21 \mathrm{a}$ & $57.50 \mathrm{a}$ \\
5-IPR 99/ Iapar & $46.25 \mathrm{~b}$ & $35.68 \mathrm{~b}$ & $40.96 \mathrm{~b}$ \\
6-Acauã & $43.75 \mathrm{~b}$ & $45.83 \mathrm{a}$ & $44.79 \mathrm{a}$ \\
7-Araponga MG 1 & $41.11 \mathrm{~b}$ & $30.83 \mathrm{~b}$ & $35.97 \mathrm{~b}$ \\
8-Palma II & $41.80 \mathrm{~b}$ & $49.82 \mathrm{a}$ & $45.81 \mathrm{a}$ \\
9-Sabiá 398 & $65.28 \mathrm{a}$ & $32.50 \mathrm{~b}$ & $51.80 \mathrm{a}$ \\
10-IPR 103 Iapar & $57.78 \mathrm{a}$ & $45.83 \mathrm{a}$ & $46.25 \mathrm{a}$ \\
11-IPR 100/Iapar & $52.22 \mathrm{a}$ & $40.28 \mathrm{a}$ & $40.69 \mathrm{~b}$ \\
12-H 4193-3-3-716-4-1 & $45.28 \mathrm{~b}$ & $36.11 \mathrm{~b}$ & $42.08 \mathrm{a}$ \\
13-H 419-10-6-2-12-1 & $42.50 \mathrm{~b}$ & $41.68 \mathrm{a}$ & $45.55 \mathrm{a}$ \\
14-Catucaí Amarelo 24/137 & $59.17 \mathrm{a}$ & $31.94 \mathrm{~b}$ & $43.84 \mathrm{a}$ \\
15-Iapar 59 & $45.89 \mathrm{~b}$ & $41.79 \mathrm{a}$ & $37.22 \mathrm{~b}$ \\
16-Oeiras & $46.11 \mathrm{~b}$ & $28.33 \mathrm{~b}$ & $34.82 \mathrm{~b}$ \\
17-Catuaí Vermelho 144 & $44.03 \mathrm{~b}$ & $25.62 \mathrm{~b}$ & $48.47 \mathrm{a}$ \\
18-Catucaí Amarelo 20/15 & $61.67 \mathrm{a}$ & $35.28 \mathrm{~b}$ & $33.54 \mathrm{~b}$ \\
19-Catiguá MG 1 & $38.47 \mathrm{~b}$ & $28.61 \mathrm{~b}$ & $44.83 \mathrm{a}$ \\
20-H 419-10-6-2-5-10-1 & $47.78 \mathrm{~b}$ & $41.87 \mathrm{a}$ & $39.91 \mathrm{~b}$ \\
21-IPR/104 Iapar & $54.82 \mathrm{a}$ & $25.00 \mathrm{~b}$ & $37.22 \mathrm{~b}$ \\
22-Sacramento MG 1 & $45.28 \mathrm{~b}$ & $29.17 \mathrm{~b}$ & $26.91 \mathrm{~b}$ \\
23-Bourbon Amarelo LCJ 10 & $36.38 \mathrm{~b}$ & $17.45 \mathrm{~b}$ & $40.28 \mathrm{~b}$ \\
24-Pau Brasil MG 1 & $46.68 \mathrm{~b}$ & $33.89 \mathrm{~b}$ & $43.05 \mathrm{a}$ \\
25-H 419-10-6-2-5-1 & $58.89 \mathrm{a}$ & $27.22 \mathrm{~b}$ & \\
\hline
\end{tabular}

Means followed by same letter do not differ by Scott Knott test at $5 \%$ probability. 
Table 5. Correlation between phenotypic characteristics of stem diameter, plant height, number of plagiotropic branches and productivity in the year 2009 of 25 coffee genotypes in the Northwestern Rio de Janeiro state

\begin{tabular}{|c|c|c|c|c|}
\hline & Plant height & Stem diameter & $\begin{array}{c}\text { Number of } \\
\text { plagiotropicbranches }\end{array}$ & Production \\
\hline Plant height & - & $0.7071 * *$ & $0.6089 * *$ & $0.3170 * *$ \\
\hline Stem diameter & & - & $0.5539 * *$ & $0.3737 * *$ \\
\hline Number of plagiotropic branche & & & - & $0.4850 * *$ \\
\hline Production & & & & - \\
\hline
\end{tabular}

** Significant at $1 \%$ probability.

Table 6. Correlation between phenotypic characteristics of stem diameter, plant height, number of plagiotropic branches and productivity in the year 2010 of 25 coffee genotypes in the Northwestern Rio de Janeiro state

\begin{tabular}{|c|c|c|c|c|}
\hline Plant height & Stem diameter & & $\begin{array}{c}\text { Number of } \\
\text { plagiotropic branches }\end{array}$ & Production \\
\hline Plant height & - & $0.7102 * *$ & $0.4703 * *$ & $0.3451^{\mathrm{NS}}$ \\
\hline Stem diameter & & - & $0.4278 * *$ & $0.0318^{\mathrm{NS}}$ \\
\hline \multicolumn{3}{|c|}{ Number of plagiotropic branches } & - & $0.2810 * *$ \\
\hline Production & & & & - \\
\hline
\end{tabular}

vegetative attributes that contributed most to increased productivity were the length of plagiotropic branches, plant height and stem diameter.

As the vegetative characteristics may be strongly influenced by variations in temperature, light, humidity, and management, among others environmental conditions, the indirect selection by means of vegetative characteristics seems to be not as efficient. Productivity (at least four harvests) is one of the most important characteristics, if not the main trait for selection of coffee genotypes, coupled with resistance to pests and diseases and quality of beverage.

\section{CONCLUSIONS}

For the conditions for the Northwest Fluminense, there was positive phenotypic correlation between plant height and stem diameter; plant height and number of plagiotropic branches; stem diameter and number of plagiotropic branches.

There was positive phenotypic correlation between vegetative characteristics and productivity in the first harvest, and in the second harvest there was a positive phenotypic correlation only between the number of plagiotropic branches and productivity.

The genotypes Catucaí Amarelo 2 SL, Catiguá MG 02, Acauã, Palma II, Sabiá 398, IPR 103/, IPR 100/, H 419-10-62-12-1, Catucaí Amarelo 24/137, Iapar 59, Catucaí Amarelo 20/15, H419-10-6-2-5-10-1 and H419-10-6-2-5-1 showed greater yields, considering the average of two crops, whereas Catiguá MG 02, IPR103 and IPR 100 had the highest consecutive yields in years 2009 and 2010. These genotypes may possibly be recommended for planting in this region, requiring the more evaluations.

\section{REFERENCES}

Alvarado GA (2005) Evolution of Hemileia vastatrix virulence in Colombia. In: Zambolim L, Zambolim EM \& Varzea VMP (Eds.) Durable resistance to coffee leaf rust. Viçosa, UFV. p.99-115.

Barbosa DHSG, Vieira HD, Souza RM, Viana AP \& Silva CP (2004) Estimativas a campo de perdas de produção e níveis de dano em lavouras cafeeiras afetadas por Meloidogyne exigua. Nematologia Brasileira, 28:49-54.

Bonomo P, Cruz CD, Viana JMS, Pereira AA, Oliveira VR \& Carneiro PCS (2004) Seleção antecipada de progênies de café descendentes de "híbrido de timor" X "catuaí amarelo" e "catuaí vermelho". Acta Scientiarum Agronomy, 26:91-96.

Brasil (2011) Registro Nacional de Cultivares. Disponível em: <http:/ /www.agricultura.gov.br>. Acessado em: 11 de maio de 2011.

Carvalho A, Scaranari HJ, Antunes Filho H \& Mônaco LC (1961) Melhoramento do cafeeiro. 22. Resultados obtidos no ensaio de eleições regionais de Campinas. Bragantia, 20:711-740.

Carvalho AM, Mendes ANG, Carvalho GR, Botelho CE, Gonçalves FMA \& Ferreira AD (2010) Correlação entre crescimento e produtividade de cultivares de café em diferentes regiões de Minas Gerais, Brasil. Pesquisa Agropecuária Brasileira, 45:269275.

Castillo ZJ (1989) Breeding for rust resistance in Colombia. In: Kushalappa AC \& Eske AB (Eds.) Coffee rust: epidemiology, resistance and management. Boca Raton, CRC Press. p.307316.

Centro de Comércio de Café do Rio de Janeiro (2010) Café no Rio: Evolução da Produção. Disponível em: <http:// www.cccrj.com.br/rio/producao.html>. Acessado em: 15 de março de 2011.

Cruz CD (2006) Programa Genes (versão windows): aplicativos computacionais em genética e estatística. Viçosa, UFV. 648p. 
Freitas ZMTS (2004) Características fenológicas de cafeeiros (Coffea arabica L.) em pós-plantio no Agreste de Pernambuco. Tese de Doutorado. Universidade Federal de Lavras, Lavras. $52 \mathrm{p}$

Freitas ZMTS, Oliveira FJ, Carvalho SP, Santos VF \& Santos JPO (2007) Avaliação de caracteres quantitativos relacionados com o crescimento vegetativo entre cultivares de café arábica de porte baixo. Bragantia, 66:267 275 .

Martorano LG, Rossiello ROP, Meneguelli NA, Lumbreras JF, Valle LSS, Motta PEF, Rebello ERG, Said UP \& Martins GS (2003) Aspectos climáticos do Noroeste Fluminense, RJ. Rio de Janeiro, Embrapa Solos. 28p. (Documento, 43).

Martinez HEP, Augusto HS, Cruz CD, Pedrosa AW \& Sampaio NF (2007) Crescimento vegetativo de cultivares de café (Coffea arabica L.) e sua correlação com a produção em espaçamentos adensados. Acta Scientiarum Agronomy, 29:481-489.

Matiello JB, Garcia AWR \& Almeida SR (2009) Como formar cafezais produtivos. $1^{\mathrm{a}}$ ed. Varginha, Fundação Procafé. 150p.
Miranda JM, Perecin D \& Pereira AA (2005) Produtividade e resistência à ferrugem do cafeeiro (Hemileia vastatrix Berk. Et. Br.) de progênies F5 de Catuaí Amarelo com o Híbrido de Timor. Ciência e Agrotecnologia, 29:1195-1200.

Rena AB, Nacif AP, Guimarães PTG \& Bartholo FG (1998) Plantios adensados de café: Aspectos morfológicos, ecofisilógicos, fenológicos e agronômicos. Informe Agropecuário, 19:61-70.

Sakiyama NS, Pereira AA \& Zambolim L (1999) Melhoramento do cafeeiro. In: Borém A (Ed.) Melhoramento de espécies cultivadas. Viçosa, UFV. p.189-204.

Severino LS, Sakiyama NS, Pereira AA, Miranda GV, Zambolim L \& Barros UV (2002) Associações da produtividade com outras características agronômicas de café (Coffea arabica L. "Catimor"). Acta Scientiarum Agronomy, 24:1467-1471.

Silvarolla MB, Guerreiro Filho O, Lima MMA \& Fazuoli LC (1997) Avaliação de progênies derivadas do híbrido de Timor com resistência ao agente da ferrugem. Bragantia, 56:47-58.

Srinivasan CS (1982) Pre-selection for yield in coffee. Indian Journal of Genetics, 42:15-19. 